\title{
Activation of topoisomerase II-mediated excision of chromosomal DNA loops during oxidative stress
}

\author{
Tsai-Kun Li, Allen Y. Chen, Chiang Yu, Yong Mao, Huimin Wang, and Leroy F. Liu ${ }^{1}$ \\ Department of Pharmacology, University of Medicine and Dentistry of New Jersey (UMDNJ)-Robert Wood Johnson Medical \\ School, Piscataway, New Jersey 08854 USA
}

\begin{abstract}
Hydrogen peroxide $\left(\mathrm{H}_{2} \mathrm{O}_{2}\right)$, a reactive oxygen species (ROS), is known to induce oxidative stress and apoptosis. U937 cells treated with $\mathrm{H}_{2} \mathrm{O}_{2}$ were shown to produce high molecular weight (HMW) DNA fragments $\sim 50$ to $100 \mathrm{~kb}$ in size in $<1 \mathrm{~min}$. The formation of these HMW DNA fragments is reversible and shown to be mediated by DNA topoisomerase II (TOP2). Following this initial event, formation of irreversible HMW DNA fragments and nucleosomal ladders occurs. Our results thus demonstrate a potential role of TOP2 in oxidative damage of DNA and apoptotic cell death.
\end{abstract}

[Key Words: TOP2; $\mathrm{H}_{2} \mathrm{O}_{2} ;$ VM-26; oxidative stress; apoptosis]

Received March 2, 1999; revised version accepted May 4, 1999.

Reactive oxygen species (ROS; e.g., $\mathrm{H}_{2} \mathrm{O}_{2}$, hydroxyl radical, and superoxide) generated during oxidative stress are known to cause a variety of cellular injuries including DNA and protein damage, lipid peroxidation, and damages to other biomolecules (for review, see Berlett and Stadtman 1997; Croteau and Bohr 1997). Oxidative stress is also widely demonstrated to occur during apoptotic cell death (Bredesen 1995; Quillet-Mary et al. 1995; Um et al. 1996; Kroemer et al. 1997; Ha et al. 1997). In fact, $\mathrm{H}_{2} \mathrm{O}_{2}$, a ROS generated during oxidative stress, is known to induce apoptosis (Stangel et al. 1996). It has been reported that Bcl-2 may exert its apoptosis-suppressing effect through an antioxidant mechanism (Hockenery et al. 1993; Ellerby et al. 1996; Hedley and McCulloch 1996). One of the hallmarks of apoptotic cell death is the fragmentation of nuclear DNA into nucleosomal DNA ladders (Liu et al. 1997; Sakahira et al. 1998). However, recent studies have demonstrated that cleavage of DNA into high molecular weight (HMW) DNA fragments ( 50 - to $100-\mathrm{kb}$ loop-sized DNA fragments) is the early event in chromatin degradation and may be the initial committed step during apoptosis (Oberhammer et al. 1993; Cohen et al. 1994; Sun and Cohen 1994; Lagarkova et al. 1995). A number of nucleases have been implicated in HMW DNA fragmentation (Sun and Cohen 1994; Krieser and Eatman 1998). Interestingly, cellular DNA cleavage into HMW DNA fragments during apoptosis is highly reminiscent of topoisomerase II (TOP2)-mediated HMW DNA fragmentation in cells (Lagarkova et al. 1995; Stanulla et al. 1997). In fact, the pattern of HMW

${ }^{1}$ Corresponding author.

E-MAIL lliu@umdnj.edu; FAX (732) 235-4073.
DNA fragmentation induced by TOP 2 poisons, and that produced in apoptotic cells induced by other stimuli, are found to be similar (Lagarkova et al. 1995; Stanulla et al. 1997). However, the relationship between TOP2, oxidative stress, and excision of chromosomal loops during apoptotic cell death is still unclear.

TOP2 is known to be critically involved in both cell proliferation and cell death. Its major function is to regulate the topological state of DNA during DNA replication, and chromosome condensation and segregation through its delicate act of breaking/rejoining DNA strands (for review, see Liu 1989; Poljak and Kas 1995; Wang 1996). Many xenobiotics (e.g., antibiotics and antitumor drugs) and peptide toxins (e.g., CcdB and microcin B17) are known to poison TOP2 (i.e., to induce TOP2-mediated DNA cleavage) resulting in cell death (for review, see Liu 1989; Wang 1996). More recently, several new mechanisms including DNA structural modifications (e.g., abasic sites), enzyme modifications (e.g., thiol alkylation), and acidic $\mathrm{pH}$ environment (pH 5 to 6) have also been shown to activate TOP2-mediated DNA cleavage (Liu et al. 1983; Zechiedrich 1989; Frydman et al. 1997; Kingma and Osheroff 1997a,b; Kwok and Hurley 1998). It appears that TOP2 is highly vulnerable to various perturbations during its delicate cleavage/religation reactions.

To test whether ROS can activate TOP2-mediated DNA cleavage, we have examined the effect of $\mathrm{H}_{2} \mathrm{O}_{2}$ in the excision of loop-sized DNA fragments in U937 myeloid leukemia cells. Surprisingly, $\mathrm{H}_{2} \mathrm{O}_{2}$ can induce rapid and reversible cleavage of chromosomal DNA into 50- to $100-\mathrm{kb}$ HMW fragments. The results presented in our current study suggest that $\mathrm{H}_{2} \mathrm{O}_{2}$ activates TOP2-me- 
diated excision of chromosomal DNA loops, which may represent an early step in apoptotic cell death.

\section{Results}

$\mathrm{H}_{2} \mathrm{O}_{2}$ and $\mathrm{VM}$-26 induce rapid excision of loop-sized DNA fragments from chromosomal DNA

U937 cells were encapsulated into agarose plugs and treated with either $\mathrm{H}_{2} \mathrm{O}_{2}$ or VM-26. The time course of the induction of HMW DNA fragments in U937 cells treated with $30 \mathrm{~mm} \mathrm{VM-26}$ and $30 \mu \mathrm{M} \mathrm{H}_{2} \mathrm{O}_{2}$ are shown in Figure 1A. Both drugs exhibited dose-dependent induction of HMW DNA fragments as revealed by pulsed-field gel electrophoresis (PFGE) and were about equicytotoxic at these concentrations (data not shown). Within $15 \mathrm{sec}$, both treatments resulted in extensive degradation of chromosomal DNA into HMW DNA fragments with a limiting size $\sim 50 \mathrm{~kb}$ (Fig. 1A). The extent of DNA fragmentation was about the same for both drugs at their respective concentrations.

\section{$\mathrm{H}_{2} \mathrm{O}_{2}$ - and VM-26-induced excision of loop-sized DNA} fragments is reversible

It is known that induction of HMW DNA fragments by VM-26 was due to the formation of reversible TOP2 cleavable complexes (Liu et al. 1983; Hsiang and Liu 1989). To test whether induction of HMW DNA fragments by $\mathrm{H}_{2} \mathrm{O}_{2}$ was also due to the formation of reversible TOP2 cleavable complexes, we examined the reversibility of the HMW DNA fragments. Heat-induced reversal (i.e., $55^{\circ} \mathrm{C}$ for $10 \mathrm{~min}$ ) is one of the unique properties of TOP2 cleavable complexes (Hsiang and Liu 1989). When drug-treated cells were heated to $55^{\circ} \mathrm{C}$ for $10 \mathrm{~min}$ prior to SDS lysis, HMW DNA fragmentation (in the 50to $100-\mathrm{kb}$ range) generated by either VM-26 or $\mathrm{H}_{2} \mathrm{O}_{2}$ treatment completely disappeared (Fig. 1A). The reversibility of the HMW DNA fragments generated by $\mathrm{H}_{2} \mathrm{O}_{2}$ has also been demonstrated by three other cleavable complex reversal conditions; removal of $\mathrm{H}_{2} \mathrm{O}_{2}$ from the medium $\left(\mathrm{H}_{2} \mathrm{O}_{2}\right.$-free medium), $4^{\circ} \mathrm{C}$ incubation, and addition of EDTA (Fig. 1B; Liu et al. 1983). These results sugget that induction of HMW DNA fragments by both VM-26 and $\mathrm{H}_{2} \mathrm{O}_{2}$ may be due to formation of TOP2 cleavable complexes. It was noted that whereas nearly all of the HMW DNA fragments induced by VM-26 were reversed to larger chromosomal DNA that did not migrate out of the well, about half of the HMW DNA fragments induced by $\mathrm{H}_{2} \mathrm{O}_{2}$ migrated to the compression zone (Fig. 1). It appeared that either the reversal was incomplete or $\mathrm{H}_{2} \mathrm{O}_{2}$ also damaged chromosomal DNA via other ROS generated in cells (Imlay et al. 1988; Croteau and Bohr 1997).

$\mathrm{H}_{2} \mathrm{O}_{2}$ - and VM-26-induced excision of loop-sized DNA fragments is reduced in a TOP2 mutant cell line

The potential role of TOP2 in mediating the effect of $\mathrm{H}_{2} \mathrm{O}_{2}$ and VM-26 was further examined with the mutant HL-60/MX-2 cell line that was selected for resistance to mitoxantrone (a TOP2-targeting drug) and known to have reduced levels of both TOP2 isozymes (Harker et al. $1995 a, b)$. Consequently, HL-60/MX-2 is known to exhibit cross-resistance to all known TOP2 poisons such as epipodophyllotoxins (e.g., VM-26 and VP-16), anthracyclines (e.g., doxorubicin and daunorubicin), and aminoacridines (e.g., m-AMSA) but not other anticancer drugs (Harker et al. 1995a,b). As shown in Figure 2A, the extent of excision of the loop-sized DNA fragments in HL-60/ MX-2 cells treated with either VM-26 or $\mathrm{H}_{2} \mathrm{O}_{2}$ was greatly reduced. This result supports the notion that TOP2 is primarily responsible for the effect of $\mathrm{H}_{2} \mathrm{O}_{2}$ and
A

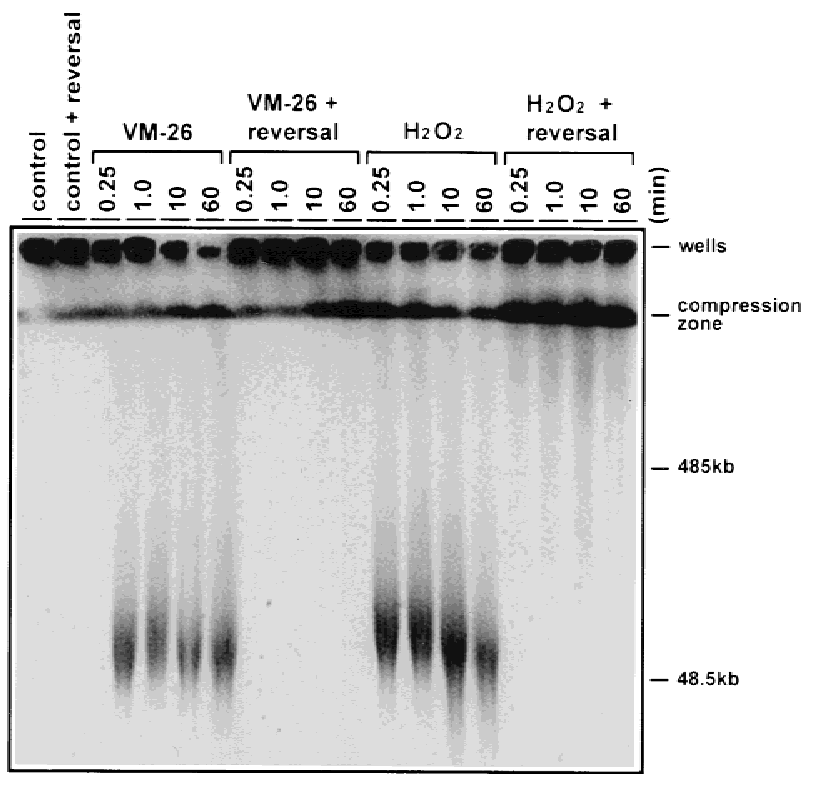

B

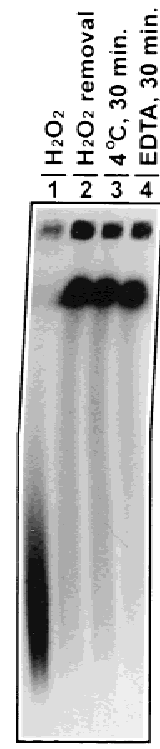

Figure 1. Rapid and reversible fragmentation of chromosomal DNA into HMW DNA fragments in U937 cells treated with VM-26 and $\mathrm{H}_{2} \mathrm{O}_{2}$. (A) PFGE was carried out to analyze the HMW DNA fragments generated in U937 cells treated with VM-26 (30 $\mu \mathrm{M})$ and $\mathrm{H}_{2} \mathrm{O}_{2}(30 \mathrm{~mm})$. Reversal of DNA cleavage by brief heating $\left(55^{\circ} \mathrm{C}\right.$ for $\left.10 \mathrm{~min}\right)$ was performed as described in Materials and Methods. (B) Encapsulated U937 cells in agarose plugs were treated with $\mathrm{H}_{2} \mathrm{O}_{2}$ (30 mM) for $30 \mathrm{~min}$ (lane 1). Subsequently, the agarose plugs were incubated for another 30 min under the following reversal conditions. (Lane 2) The medium was replaced with fresh medium (removal of $\mathrm{H}_{2} \mathrm{O}_{2}$ ) and the incubation continued at $37^{\circ} \mathrm{C}$; (lane 3) the agarose plug in the $\mathrm{H}_{2} \mathrm{O}_{2}$-containing medium was placed at $4^{\circ} \mathrm{C}$; (lane 4) EDTA (final $10 \mathrm{~mm}$ ) was added to the $\mathrm{H}_{2} \mathrm{O}_{2}$-containing medium and incubation continued at $37^{\circ} \mathrm{C}$. 
A

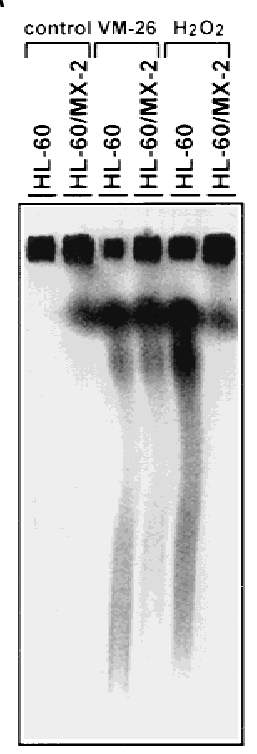

C

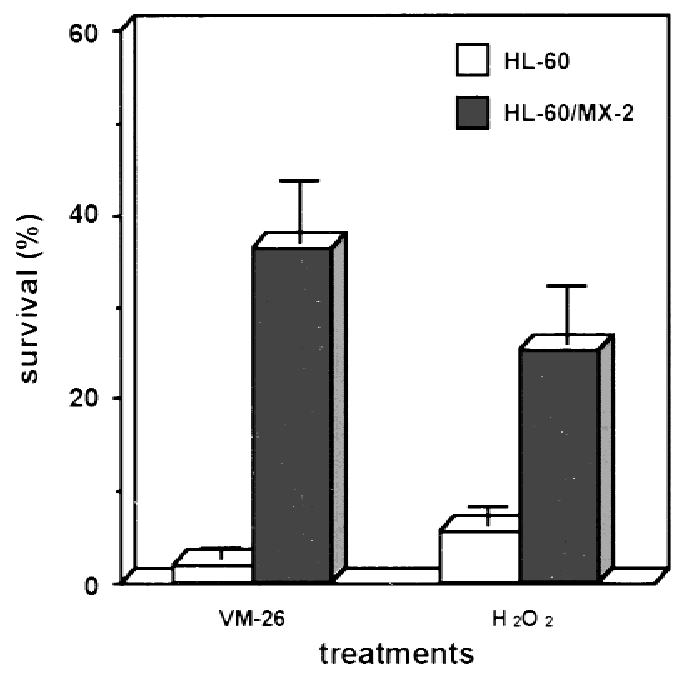

Figure 2. A TOP2 mutant cell line is resistant to both $\mathrm{H}_{2} \mathrm{O}_{2}$ and VM-26. HL-60/MX-2 is known to be cross-resistant to all TOP2 poisons primarily due to the reduced TOP2 level in the nucleus (Harker et al. 1995a,b). (A) HL-60 and HL-60/MX-2 cells were encapsulated into agarose plugs and treated with VM-26 $(30 \mu \mathrm{M})$ and $\mathrm{H}_{2} \mathrm{O}_{2}(30 \mathrm{~mm})$. PFGE was carried out as described in Materials and Methods. (B) HL-60 and HL-60/MX-2 cells were treated with VM-26 and $\mathrm{H}_{2} \mathrm{O}_{2}$ for $5 \mathrm{hr}$ at $37^{\circ} \mathrm{C}$. Subsequently, cells were lysed by SDS, cell lysates were treated with PK, and DNA was isolated by the published procedure (Shih and Shaman 1996). Gel electrophoresis was performed in $1.8 \%$ agarose gel in 1/2× TPE buffer. (Lane 1) Control; (lane 2) $0.1 \mu \mathrm{M}$ VM-26; (lane 3) $1 \mu \mathrm{M}$ VM-26; (lane 4) $0.1 \mathrm{mM} \mathrm{H}_{2} \mathrm{O}_{2}$; (lane 5) $1 \mathrm{mM} \mathrm{H}_{2} \mathrm{O}_{2}$. (C) ( $\square$ ) HL-60 and (口) HL-60/MX-2 cells were treated with 10 $\mu \mathrm{M}$ VM-26 or $10 \mathrm{~mm} \mathrm{H}_{2} \mathrm{O}_{2}$ for $1 \mathrm{hr}$ at $37^{\circ} \mathrm{C}$. Subsequently, cells were washed once and incubated in fresh (drug-free) medium. MTT assay was performed at the end of the fourth day.

VM-26 in the excision of loop-sized DNA fragments. We have also examined the effect of $\mathrm{H}_{2} \mathrm{O}_{2}$ and VM-26 in activating the nucleases involved in fragmentation of chromosomal DNA into nucleosomal ladders. Again, formation of nucleosomal DNA ladders, a hallmark of apoptotic cell death, was lacking in HL-60/MX-2 cells treated with either VM-26 or $\mathrm{H}_{2} \mathrm{O}_{2}$ (Fig. 2B). Furthermore, HL-60/MX-2 cells were shown to be cross-resistant to both VM-26 and $\mathrm{H}_{2} \mathrm{O}_{2}$ in a cytotoxicity assay (Fig. $2 \mathrm{C})$. These results together suggest that the major cytotoxic target of VM-26 and $\mathrm{H}_{2} \mathrm{O}_{2}$ is TOP2 in HL-60 cells, and that both drugs can activate TOP2-mediated DNA damage.

\section{Reversible excision of loop-sized DNA fragments precedes extensive degradation of chromosomal DNA}

The fate of the HMW DNA fragments in U937 cells treated with either $\mathrm{H}_{2} \mathrm{O}_{2}$ or VM-26 was monitored by extending the time of drug treatment up to $1000 \mathrm{~min}$. Two events were noticed. First, after $100 \mathrm{~min}$ of treatment with either drug, the HMW DNA fragments were no longer reversible by heat treatment (Fig. 3). Second, further degradation of the HMW DNA fragments started at $400 \mathrm{~min}$ in cells treated with either drug (see the
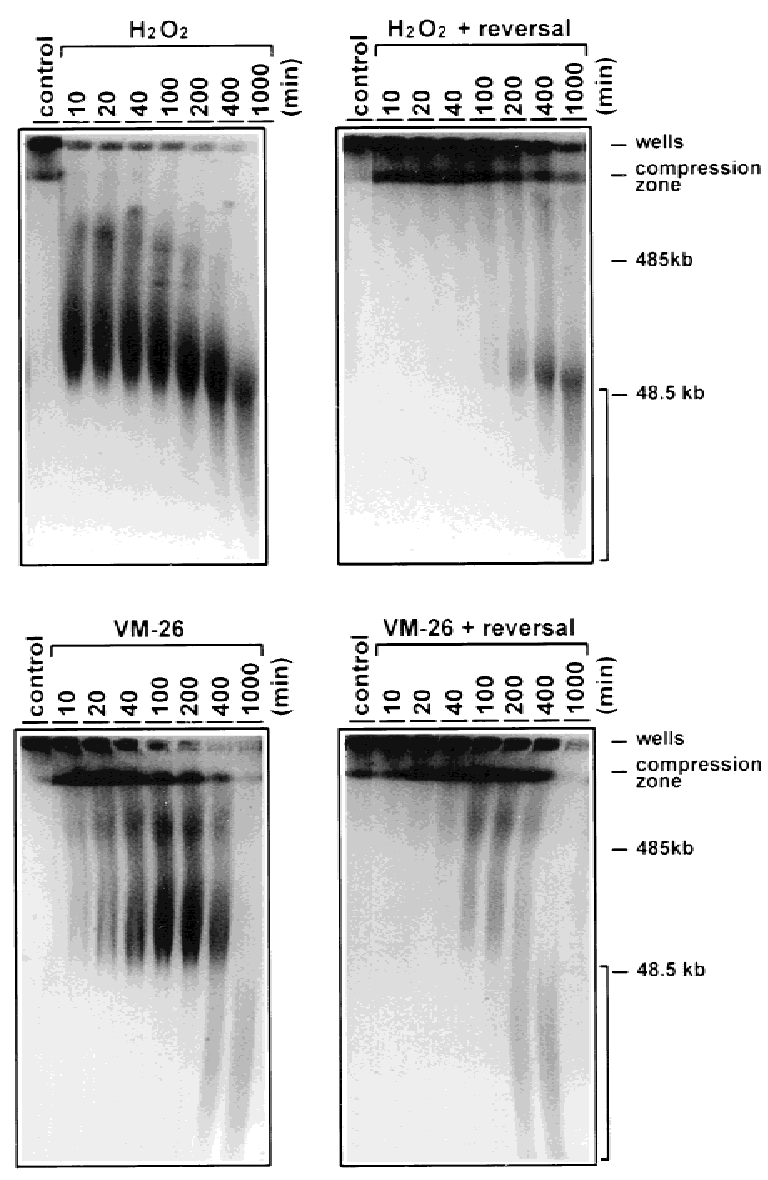

Figure 3. Time-dependent processing of the HMW DNA in U937 cells treated with $\mathrm{H}_{2} \mathrm{O}_{2}$ and VM-26. PFGE analysis of the HMW DNA was performed as described in the legend to Fig. 1, except that the time course was extended to $1000 \mathrm{~min}$. The bracketed area represents DNA fragments $<50 \mathrm{~kb}$ in size. 
Li et al.

bracketed regions in Fig. 3). Nucleosomal ladders appeared at about the same time (data not shown). These results suggest that reversible excision of loop-sized DNA fragments precedes both irreversible excision of HMW DNA fragments and extensive degradation of chromosomal DNA by nuclease(s).

\section{$\mathrm{H}_{2} \mathrm{O}_{2}$ induces DNA fragmentation in the presence of purified DNA TOP2}

To ascertain that TOP2 is responsible for $\mathrm{H}_{2} \mathrm{O}_{2}$-induced excision of chromosomal DNA loops, purified topoisom- erases were used for in vitro experiments. As shown in Figure 4A, $\mathrm{H}_{2} \mathrm{O}_{2}$, like VM-26, induced DNA fragmentation in the presence of calf thymus TOP2. The DNA cleavage activity of $\mathrm{H}_{2} \mathrm{O}_{2}$ was not restricted to calf thymus TOP2. Both human TOP $2 \alpha$ - and TOP $2 \beta$-mediated DNA cleavages were similarly induced by $\mathrm{H}_{2} \mathrm{O}_{2}$ (Fig. 4B). However, in the same concentration range, $\mathrm{H}_{2} \mathrm{O}_{2}$ had no effect on calf thymus TOP1-mediated DNA cleavage (Fig. 4C). Interestingly, ATP (1 mM) had a 50- to 100-fold stimulatory effect on VM-26-induced DNA cleavage. However, $\mathrm{H}_{2} \mathrm{O}_{2}$-induced DNA cleavage was only minimally (severalfold) affected by ATP (Fig. 4A).

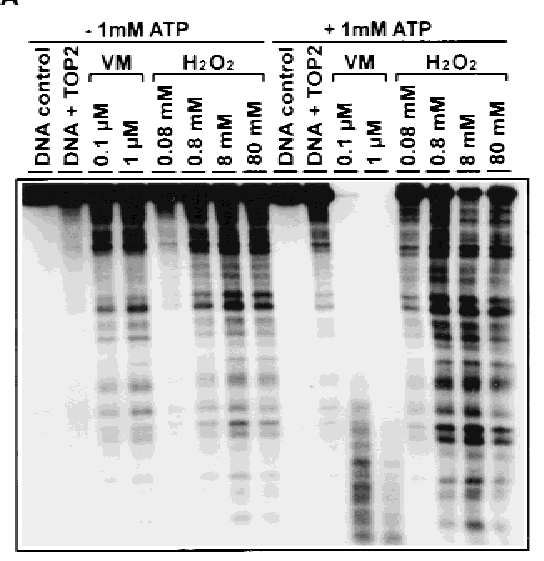

B

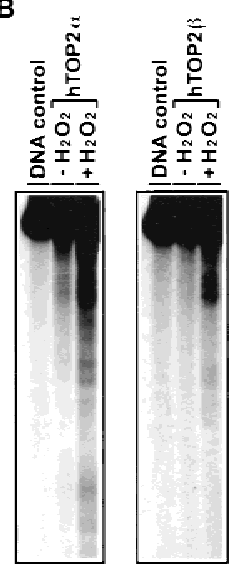

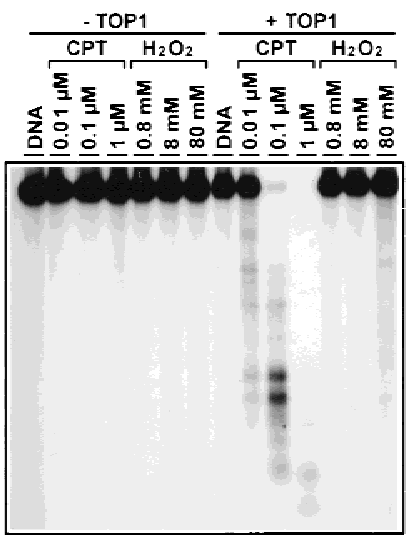

D

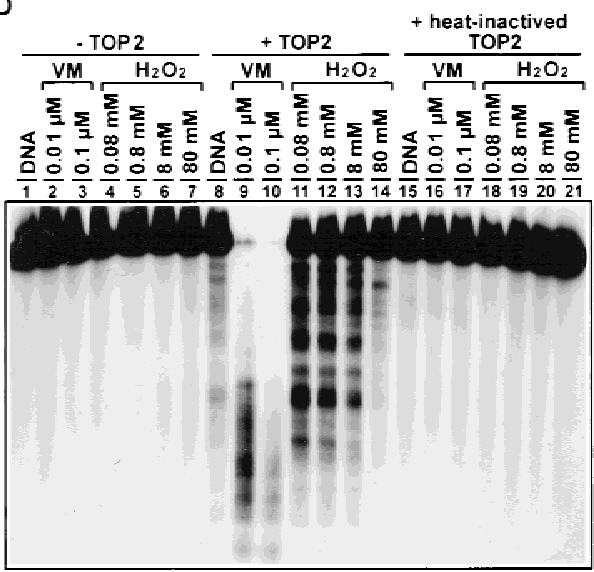

E

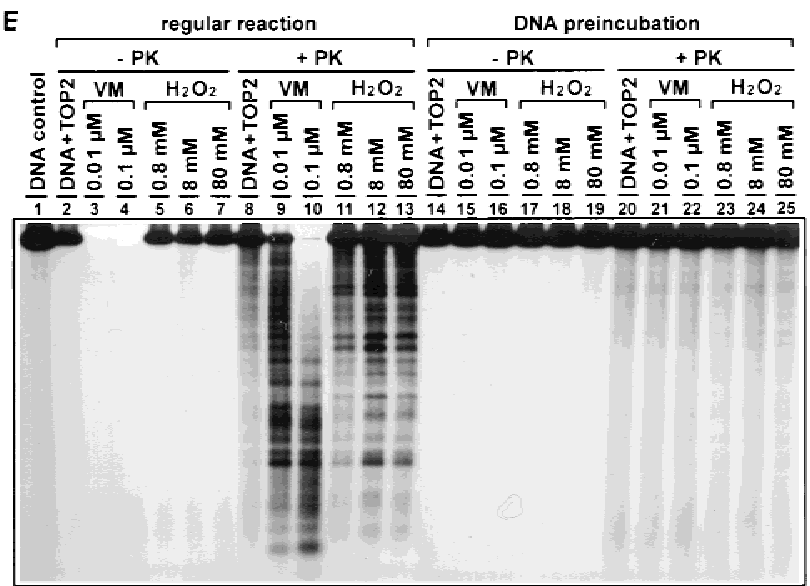

Figure 4. $\mathrm{H}_{2} \mathrm{O}_{2}$ stimulates TOP2- but not TOP1-mediated DNA cleavage. (A) Stimulation of calf thymus TOP2-mediated DNA cleavage by $\mathrm{H}_{2} \mathrm{O}_{2}$. The reaction mixture for each of the last eight lanes contained $1 \mathrm{~mm}$ ATP (see separately bracketed lanes). (B) Stimulation of hTOP2 $\alpha$ - and hTOP2 $\beta$-mediated DNA cleavage by $\mathrm{H}_{2} \mathrm{O}_{2} ; 3 \mathrm{~mm} \mathrm{H}_{2} \mathrm{O}_{2}$ was used in these reactions. $(C) \mathrm{H}_{2} \mathrm{O}_{2}$ does not stimulate TOP1-mediated DNA cleavage. $(D)$ DNA double-strand breaks stimulated by $\mathrm{H}_{2} \mathrm{O}_{2}$ require active TOP2. The reactions were performed in three sets, one set without added TOP2, one set with added TOP2, and the other with heat-inactivated TOP2 $\left(65^{\circ} \mathrm{C}\right.$ for $15 \mathrm{~min}$ ) (see three separately bracketed lanes). (E) DNA fragments induced by $\mathrm{H}_{2} \mathrm{O}_{2}$ are protein linked. After incubation of cleavage reactions, one set of reactions was terminated by treatment with $1 \%$ SDS in the absence of PK (another 60 min at $37^{\circ} \mathrm{C}$ ) (see bracketed lanes under-PK). A duplicate set of reactions was terminated with $1 \%$ SDS plus $400 \mu \mathrm{g} / \mathrm{ml} \mathrm{PK}$ and then incubation continued at $37^{\circ} \mathrm{C}$ for another $60 \mathrm{~min}$ (see bracketed lanes under $+\mathrm{PK}$ ). The last half of the panel (last 13 lanes) were identical to the first half of panel (first 13 lanes), except that labeled DNA was first reacted with VM-26 or $\mathrm{H}_{2} \mathrm{O}_{2}$ in the absence of TOP2. Drug-treated DNA was then extracted with phenol and precipitated with ethanol, and resuspended in reaction mixtures containing calf thymus TOP2. All topoisomerase DNA cleavage assays were performed as described in Materials and Methods. Except for $B$, in which recombinant hTOP $2 \alpha$ and hTOP2 $\beta$ were used, calf thymus topoisomerases were used in all cleavage assays. The concentrations of VM-26 (VM), camptothecin $(\mathrm{CPT})$, and hydrogen peroxide $\left(\mathrm{H}_{2} \mathrm{O}_{2}\right)$ were as indicated at the top of each lane. 
Two additional experiments were performed to show that DNA cleavage induced by $\mathrm{H}_{2} \mathrm{O}_{2}$ required active TOP2 and resulted in TOP2-linked DNA breaks. First, $\mathrm{H}_{2} \mathrm{O}_{2}$ was shown to have no effect on DNA cleavage in the absence of TOP2 (Fig. 4D, lanes 1-7) or in the presence of heat-inactivated TOP2 (Fig. 4D, lanes 15-21). Stimulation of DNA cleavage by $\mathrm{H}_{2} \mathrm{O}_{2}$ was observed only in the presence of active TOP2 (Fig. 4D, lanes 8-14). In the presence of active TOP2, DNA cleavage was progressively reduced with increasing concentrations of $\mathrm{H}_{2} \mathrm{O}_{2}>8 \mathrm{~mm}$ (Fig. 4D, lanes 8-14), possibly due to nonspecific oxidation and, hence, inactivation of TOP2. Second, all DNA fragments induced by $\mathrm{H}_{2} \mathrm{O}_{2}$ were shown to be protein linked as evidenced by their disappearance from the aqueous phase after phenol extraction (Fig. 4E, lanes 1-7). On the other hand, if the reaction mixtures were digested with proteinase $\mathrm{K}(\mathrm{PK})$ prior to phenol extraction, all DNA fragments were recovered in the aqueous phase (Fig. 4E, cf. +PK with $-\mathrm{PK}$ in lanes 2-13), suggesting that all DNA fragments were protein linked. If DNA was preincubated with VM-26 or $\mathrm{H}_{2} \mathrm{O}_{2}$ for 30 min at $37^{\circ} \mathrm{C}$ and reisolated for subsequent incubation with TOP2 (no VM-26 or $\mathrm{H}_{2} \mathrm{O}_{2}$ in the second stage incubation), no significant cleavage was observed (Fig. 4E, lanes 14-25).

\section{$\mathrm{H}_{2} \mathrm{O}_{2}$-induced TOP2-mediated DNA cleavage in vitro is reversible}

To test whether the TOP2-mediated DNA cleavage stimulated by $\mathrm{H}_{2} \mathrm{O}_{2}$ was due to the increased formation of reversible cleavable complexes, the cleavage reaction was subjected to two standard reversal tests (Liu et al. 1983; Hsiang and Liu 1989). First, a brief heating $\left(65^{\circ} \mathrm{C}\right.$ for $15 \mathrm{~min}$ ) of the reaction mixture just prior to termi- nation (with SDS) of the cleavage reaction was shown to reverse DNA cleavage (heat-induced reversal) (Fig. 5A). Second, addition of excess EDTA (10 $\mathrm{mm}$ ) to chelate $\mathrm{Mg}$ (II) ion was shown to completely reverse DNA cleavage induced by $\mathrm{H}_{2} \mathrm{O}_{2}$ and VM-26 (Fig. 5B).

\section{Discussion \\ Molecular basis for $\mathrm{H}_{2} \mathrm{O}_{2}$-dependent activation of TOP2-mediated DNA cleavage}

The molecular basis for TOP2 poisoning (i.e., activation of TOP2-mediated DNA cleavage) by $\mathrm{H}_{2} \mathrm{O}_{2}$ is unclear. However, recent studies have demonstrated that TOP2 can be poisoned by multiple mechanisms (Liu et al. 1983; Zechiedrich 1989; Frydman et al. 1997; Kingma and Osheroff 1997a,b; Kwok and Hurley 1998). For example, in addition to drugs that bind TOP2 or TOP2DNA complexes, DNA lesions have been shown to act as site-specific TOP2 poisons (Kingma and Osheroff 1997a,b; Kwok and Hurley 1998). We have therefore tested whether DNA damaged by $\mathrm{H}_{2} \mathrm{O}_{2}$ is responsible for activation of TOP2-mediated DNA cleavage. Our results do not support this possibility. DNA preincubated with $\mathrm{H}_{2} \mathrm{O}_{2}$ [with or without $\mathrm{Fe}$ (II) and EDTA] did not lead to significant stimulation of TOP2-mediated DNA cleavage (Fig. 4E; unpublished results).

Another new mechanism for poisoning TOP2 is through thiol alkylation of TOP2 (Frydman et al. 1997). The characteristics of TOP2 cleavage stimulated by $\mathrm{H}_{2} \mathrm{O}_{2}$ are quite reminiscent of that by thiol-alkylating naphthoquinones and other thiol-reactive compounds. Thiol alkylators have been suggested to activate TOP2mediated DNA cleavage by covalently modifying the enzyme-DNA complex (Frydman et al. 1997; H. Wang and L.F. Liu, unpubl.). A cysteineless mutant yeast TOP2
A

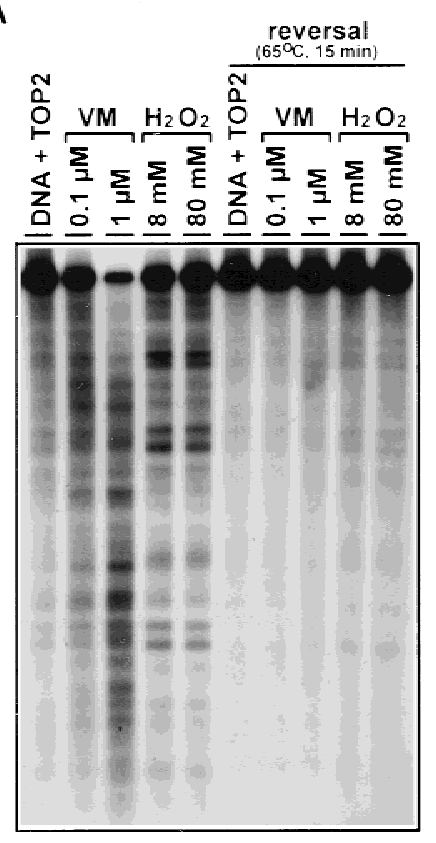

B

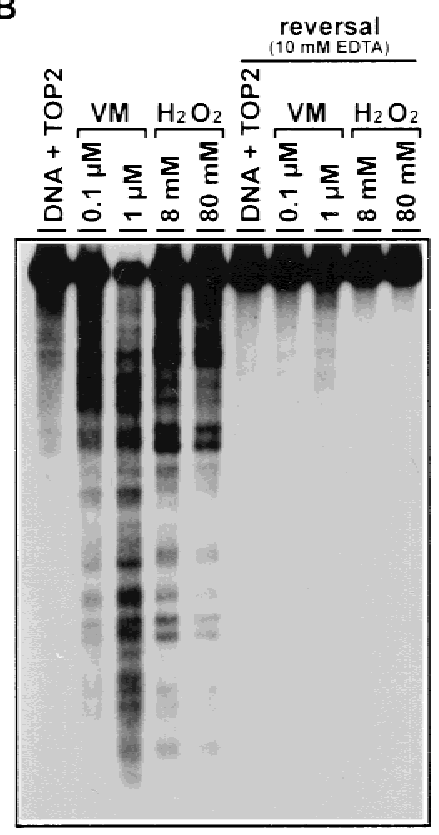

Figure 5. TOP2-mediated DNA cleavage stimulated by $\mathrm{H}_{2} \mathrm{O}_{2}$ is reversible. TOP2-mediated DNA cleavage assays were performed as described in Materials and Methods. Drug concentrations were indicated at the top of each lane. After incubation, duplicate reactions were subjected to different reversal treatments (see bracketed lanes under reversal) for $15 \mathrm{~min}$ prior to termination with SDS plus PK. (A) The reversal treatment was brief heating at $65^{\circ} \mathrm{C}$ for $15 \mathrm{~min} .(B)$ The reversal treatment was performed with $10 \mathrm{~mm}$ EDTA at $37^{\circ} \mathrm{C}$ for $15 \mathrm{~min}$. 
was shown to be completely resistant to activation by thiol-alkylating naphthoquinones, suggesting that cysteine modification may be involved in activation of TOP2mediated DNA cleavage (H. Wang and L.F. Liu, unpubl.). It seems conceivable that $\mathrm{H}_{2} \mathrm{O}_{2}$ may activate TOP2-mediated DNA cleavage through oxidation of a critical thiol group(s) on TOP2. Clearly, further studies are necessary to elucidate this interesting TOP2 poisoning mechanism.

\section{TOP2-mediated DNA damage in oxidative stress and apoptotic cell death}

TOP2 poisons are known to induce apoptotic cell death (Walker et al. 1991; Clarke et al. 1993; Lowe et al. 1993). Furthermore, TOP2 poisons have also been used to excise chromosomal DNA loops in cells (Lagarkova et al. 1995; Poljak and Kas 1995). Because oxidative stress and HMW fragmentation are commonly observed during the early stages of apoptosis (Quillet-Mary et al. 1995; Ha et al. 1997), poisoning of TOP2 by $\mathrm{H}_{2} \mathrm{O}_{2}$ may have interesting implications in apoptotic cell death. Oxidative stress is thought to cause DNA breaks and base modifications through hydroxyl radicals. The DNA breaks are primarily in the form of single-strand breaks (Imlay et al. 1988; Croteau and Bohr 1997). Our observation that $\mathrm{H}_{2} \mathrm{O}_{2}$ can activate TOP2-mediated DNA damage, which is primarily in the form of double-strand breaks, raises the question of which form of DNA damage, if any, is primarily responsible for apoptotic cell death. On the basis of the known fact that TOP2-mediated DNA damage induced by TOP2 poisons can efficiently trigger apoptotic cell death (Walker et al. 1991; Clarke et al. 1993; Lowe et al. 1993), one should consider the possibility that TOP2-mediated DNA damage induced by $\mathrm{H}_{2} \mathrm{O}_{2}$ may be involved in triggering apoptotic cell death. In agreement with this notion, $\mathrm{H}_{2} \mathrm{O}_{2}$ has been suggested to be a common mediator in ceramide- and polyamineanalog-induced apoptotic cell death (Quillet-Mary et al. 1995; $\mathrm{Ha}$ et al. 1997). In addition, generation of $\mathrm{H}_{2} \mathrm{O}_{2}$, HMW DNA fragmentation and apoptosis can be inhibited by antioxidants, catalase, and polyamine oxidase (PAO) inhibitors (Quillet-Mary et al. 1995; Ha et al. 1997).

A scheme summarizing our results is shown in Figure 6. In this scheme, hydrogen peroxide $\left(\mathrm{H}_{2} \mathrm{O}_{2}\right)$ can covalently modify TOP2, which is located at the base of the chromosomal loops (30-100 $\mathrm{kb}$ in size) leading to the formation of reversible TOP2 cleavable complexes. TOP2-directed anticancer drugs act similarly except that their interaction with TOP2-DNA complexes is noncovalent. At this stage, addition of SDS to lyse cells would release the HMW DNA fragments. However, due to the reversibility of the cleavable complexes, a number of reversal conditions (e.g., drug removal, incubation at $55^{\circ} \mathrm{C}$ or $4^{\circ} \mathrm{C}$, and addition of EDTA) can abolish the release of the HMW DNA fragments. With increasing time, irreversible excision of loop-sized DNA fragments occurs. In this case, the fragmentation process can no longer be reversed by the reversal conditions. The nature of this

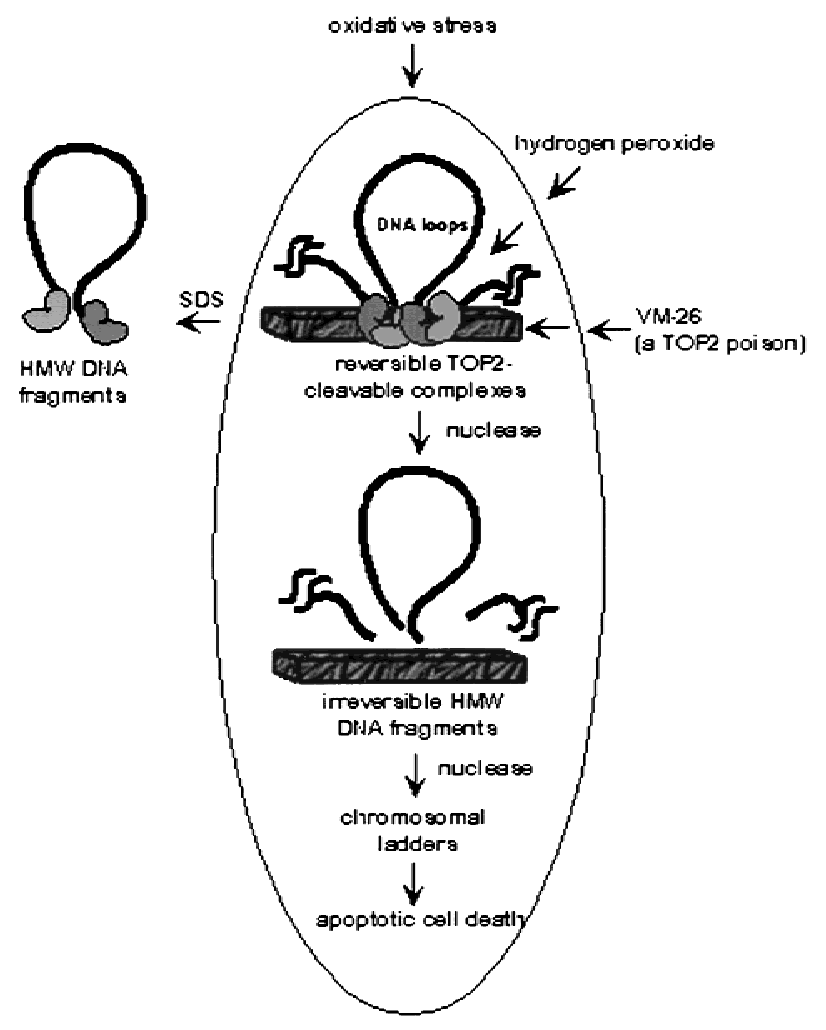

Figure 6. A schematic illustrating the kinetic events of chromosomal DNA degradation due to activation of TOP2 by $\mathrm{H}_{2} \mathrm{O}_{2}$ or TOP2-directed anticancer drugs.

transition is unclear but may involve nuclease activation (Sun and Cohen 1994; Huang et al. 1997; Krieser and Eatman 1998). Following this stage, HMW DNA fragments are further digested by nucleases into smaller DNA fragments, which can be revealed as nucleosomal DNA ladders. Cytochrome $c$ has been shown to activate a nuclease [DNA fragmentation Factor (DFF)/ caspaseactivated deoxyribonuclease, (CAD)] involving caspase 3 (Liu et al. 1997; Sakahira et al. 1998; Zhang et al. 1998). It seems possible that CAD-dependent degradation of nuclear DNA could be responsible for the late stage events observed in our studies.

TOP2, being located at the base of the chromosomal DNA loops, has been suggested to control the loop topology that can modulate critical cellular processes such as DNA replication and RNA transcription (for review, see Wang 1996). Recent studies have suggested an interaction between yeast TOP2 and SGS1. SGS1, an Escherichia coli RecQ homolog, is known to be involved in aging of yeast (Sinclair and Guarente 1997). Interestingly, the two human RecQ homologs, BLM (the Bloom's syndrome protein) and WRN (the Werner's syndrome protein), are involved in genome instability and premature aging, respectively (for review, see Kirkwood 1996; Wang 1996). Oxidative stress is often proposed to be closely associated with the process of aging (for review, see Jazwinski 1996; Kirkwood 1996; Berlett and Stadtman 1997). Whether oxidative activation of TOP2 may 
be important in both genome instability and aging remains to be answered. Our studies have demonstrated such a possibility.

\section{Materials and methods}

\section{Chemicals and cell lines}

VM-26 was obtained from Bristol-Myers Squibb Co. $\mathrm{H}_{2} \mathrm{O}_{2}$, ATP, and DMSO were purchased from Sigma Chemical Co. VM-26 was dissolved in DMSO and kept frozen in aliquots at $-20^{\circ} \mathrm{C}$. $\left[\alpha^{-32} \mathrm{P}\right] \mathrm{dATP}(3000 \mathrm{Ci} / \mathrm{mmole})$ was purchased from DuPont. U937 and HL-60 cells were obtained from Dr. Eric H. Rubin and Dr. K.V. Chin, respectively (The Cancer Institute of New Jersey, New Brunswick, NJ). The mitoxantrone-resistant variant of HL60, HL-60/MX-2, was obtained from ATCC (American Type Culture Collection).

\section{Enzymes and nucleic acids}

TOP2 was purified to near homogeneity from calf thymus glands with the published procedure (Liu et al. 1983). Human TOP $2 \beta$ (hTOP $2 \beta$ ) cDNA was isolated by RT-PCR with mRNA isolated from human U937 cells. hTOP2 $\beta$ cDNA was then used to replace the TOP2 $\alpha$ cDNA in YEpWob6 (unpubl.). The resulting plasmid, YEphTOP2 $\beta$, was used to transform protease-deficient yeast BCY123. Purification of recombinant TOP2 isozymes followed the published procedure with slight modification (Wasserman et al. 1993).

\section{Topoisomerase cleavage assay}

TOP2 cleavage assay was performed as described previously (Tewey et al. 1985). Briefly, the reaction mixture (20 $\mu \mathrm{l}$ each) containing $40 \mathrm{~mm}$ Tris- $\mathrm{HCl}(\mathrm{pH} 7.5), 100 \mathrm{~mm} \mathrm{KCl}, 10 \mathrm{~mm}$ $\mathrm{MgCl}_{2}, 1.0 \mathrm{~mm}$ ATP (unless indicated otherwise), $0.5 \mathrm{~mm}$ dithiothreitol, $0.5 \mathrm{~mm}$ EDTA, $30 \mu \mathrm{g} / \mathrm{ml}$ bovine serum albumin, 20 ng of 3' end-labeled YEpG plasimd DNA, 10 ng of TOP2, and drug were incubated at $37^{\circ} \mathrm{C}$ for $30 \mathrm{~min}$. The reactions were terminated by the addition of $5 \mu \mathrm{l}$ of $5 \%$ SDS and $1 \mathrm{mg} / \mathrm{ml} \mathrm{PK}$ with an additional $1 \mathrm{hr}$ incubation at $37^{\circ} \mathrm{C}$. Following addition of sucrose ( $5 \%$ final concentration) and bromophenol blue $(0.05$ $\mathrm{mg} / \mathrm{ml}$ final concentration), DNA samples were loaded onto a $1 \%$ agarose gel in $1 / 2 \times$ TPE $(45 \mathrm{~mm}$ Tris-phosphate, 1 mM EDTA at $\mathrm{pH}$ 8.0) buffer. After electrophoresis, gels were then dried onto Whatman $3 \mathrm{MM}$ chromatographic paper and autoradiographed at $-80^{\circ} \mathrm{C}$ with Kodak XAR-5 films. TOP1 cleavage assay (Chen et al. 1993) was performed in a similar manner with the following differences; 10 ng of calf thymus TOP1 was used instead of TOP2, and ATP was omitted. After SDS/PK treatment, samples were alkali denatured by addition of $\mathrm{NaOH}$, EDTA, sucrose, and bromophenol blue to final concentrations of $75 \mathrm{~mm}, 5 \mathrm{~mm}, 2.5 \%$, and $0.05 \mathrm{mg} / \mathrm{ml}$, respectively, prior to loading onto a neutral agarose gel described above.

\section{Encapsulation of cells into agarose plugs}

Logarithmically growing cells were pelleted and resuspended to a density of $10^{7}$ cells $/ \mathrm{ml}$ in RPMI-1640 supplemented with $10 \%$ fetal calf serum, L-glutamate $(2 \mathrm{mM})$, penicillin $(100 \mathrm{U} / \mathrm{ml})$, and streptomycin $(100 \mathrm{mg} / \mathrm{ml})$. Following mixing with an equal volume of $1.5 \%$ (wt/vol) low-melting point agarose premelted in the same culture medium $\left(37^{\circ} \mathrm{C}\right)$, the mixture $(100 \mathrm{ml}$ each) was loaded into agarose plug makers. After solidification $(5 \mathrm{~min}$ at room temperature), these agarose plugs were placed into mul- tiple-well tissue culture plates and incubated in a $\mathrm{CO}_{2}$ incubator at $37^{\circ} \mathrm{C}$.

\section{Drug treatment and heat-induced reversal}

To induce excision of chromosomal DNA loops, the agarose blocks containing cells were incubated at $37^{\circ} \mathrm{C}$ in RPMI-1640 medium supplemented with $30 \mu \mathrm{M} V M-26$ or $30 \mathrm{mM} \mathrm{H}_{2} \mathrm{O}_{2}$. At each indicated time point, one plug from each well was removed and placed in an eppendorf tube containing $1 \mathrm{ml}$ of the same medium (with or without drug) preheated to $55^{\circ} \mathrm{C}$. Heat reversal was carried out in a $55^{\circ} \mathrm{C}$ heat block for $10 \mathrm{~min}$. Another agarose plug was subjected to lysis immediately (see the next section).

\section{Cell lysis and PFGE}

Cell lysis in the plugs was accomplished by placing plugs into new Eppendorf tubes containing $500 \mathrm{ml}$ of TEN buffer $(50 \mathrm{~mm}$ Tris at $\mathrm{pH} 8.0,100 \mathrm{~mm}$ EDTA, and $100 \mathrm{~mm} \mathrm{NaCl}$ ) with $1 \%$ SDS and $0.5 \mathrm{mg} / \mathrm{ml}$ of PK. Following incubation at $50^{\circ} \mathrm{C}$ for $24 \mathrm{hr}$, the integrity of nuclear DNA in the plugs was analyzed by PFGE. PFGE was performed in the cold room $\left(4^{\circ} \mathrm{C}\right)$ for $45 \mathrm{hr}$ with circulation with $4 \mathrm{~V} / \mathrm{cm}$ and the following switching times; $60 \mathrm{sec}(21 \mathrm{hr}), 80 \mathrm{sec}(7 \mathrm{hr})$, and $120 \mathrm{sec}(17 \mathrm{hr})$. Following electrophoresis, the gel was stained with $1 \mathrm{mg} / \mathrm{ml}$ ethidium bromide and photographed.

\section{Acknowledgments}

This work was supported by the National Institutes of Health (grant nos. GM27731 and CA 39962).

The publication costs of this article were defrayed in part by payment of page charges. This article must therefore be hereby marked 'advertisement' in accordance with 18 USC section 1734 solely to indicate this fact.

\section{References}

Berlett, B.S. and E.R. Stadtman. 1997. Protein oxidative in aging, disease and oxidative stress. J. Biol. Chem. 272: 2031320316.

Bredesen, D.E. 1995. Neural apoptosis. Ann. Neurol. 38: 839851.

Chen, A.Y., C. Yu, and L.F. Liu. 1993. DNA minor groove binding ligands: A different class of mammalian DNA topoisomerase I inhibitors. Proc. Natl. Acad. Sci. 90: 8131-8137.

Clarke, A.R., C.A. Purdie, D.J. Harrison, R.G. Morris, C.C. Bird, M.L. Hooper, and A.H. Wyllie. 1993. Thymocyte apoptosis induced by $\mathrm{p} 53$-dependent and independent pathways. $\mathrm{Na}$ ture 362: 849-852.

Cohen, G.M., X.M. Sun, H. Fearnhea, M. MacFarlane, D.G. Brown, R.T. Snowden, and D. Dinsdale. 1994. Formation of large molecular weight fragments of DNA is a key committed step of apoptosis in thymocytes. I. Immunol. 153: 507516.

Croteau, D.L. and V. Bohr. 1997. Repair of oxidative damage to nuclear and mitochondrial DNA in mammalian cells. J. Biol. Chem. 272: 25409-25412.

Ellerby, L.M., H.M. Ellerby, S.M. Park, A.L. Holleran, A.N. Murphy, G. Fiskum, D.J. Kane, M.P. Testa, C. Kayalar, and D.E. Bredesen. 1996. Shift of the cellular oxidation-reduction potential in neural cells expressing Bcl-2. J. Neurochem. 67: 1259-1267.

Frydman, B., L.J. Marton, J.S. Sun, K. Neder, A.A. Liu, H.M. Wang, Y. Mao, H.Y. Wu, M.M. Sanders, and L.F. Liu. 1997. 
Induction of DNA topoisomerase II-mediated DNA cleavage by beta-lapachone and related naphthoquinones. Cancer Res. 57: 620-627.

Ha, H.A., P.M. Woster, J.D. Yager, and R.A. Casero Jr. 1997. The role of catabolism in polyamine analog-induced programmed cell death. Proc. Nat1. Acad. Sci. 94: 11557-11562.

Harker, W.G., D.L. Slade, R.L. Parr, P.W. Feldhoff, D.M. Sullivan, and H.M. Holguin. 1995a. Alteration in the topoisomerase II $\alpha$ gene, message RNA, and subcellular protein distribution as well as reduced expression of the DNA topoisomerase II $\beta$ enzyme in a mitoxantrone-resistant HL-60 human leukemia cell line. Cancer Res. 55: 1707-1716.

Harker, W.G., D.L. Slade, R.L. Parr, and H.M. Holguin. 1995b. Selective use of an alternative stop codon and polyadenylation signal within intron sequences leads to a truncated topoisomerase II $\alpha$ message RNA and protein in human HL-60 leukemia cell line selected for resistance to mitoxantrone. Cancer Res. 55: 4962-4971.

Hedley, D.W. and E.A. McCulloch. 1996. Generation of reactive oxygen intermediates after treatment of blasts of acute myeloblastic leukemia with cytosine arabinoside: Role of $b c l-2$. Leukemia 10: 1143-1149.

Hockenery, D.M., Z.N. Oltvai, X.M. Yin, C.L. Milliman, and S.J. Korsmeyer. 1993. Bcl-2 functions in an antioxidant pathway to prevent apoptosis. Cell 75: 241-251.

Hsiang, Y.-H. and L.F. Liu. 1989. Evidence for the reversibility of cellular DNA lesion induced by mammalian topoisomerase II poisons. J. Biol. Chem. 264: 9713-9715.

Huang, P., K. Ballal, and W. Plunkett. 1997. Biochemical characterization of the protein activity responsible for high molecular weight DNA fragmentation during drug-induced apoptosis. Cancer Res. 57: 3407-3414.

Imlay, J.A., S.M. Chin, and S. Linn. 1988. Toxic DNA damage by hydrogen peroxide through the fenton reaction in vivo and in vitro. Science 240: 640-642.

Jazwinski, S.M. 1996. Longevity, genes and aging. Science 273: 54-58.

Kingma, P.S. and N. Osheroff. 1997a. Apurinic sites are positionspecific topoisomerase II poisons. J. Biol. Chem. 272: 11481155 .

-1997b. Spontaneous DNA damage stimulates topoisomerase II-mediated DNA cleavage. J. Biol. Chem. 272: 7488 7493.

Kirkwood, T.B. 1996. Human senescence. BioEssays 18: 10091016.

Krieser, R.J. and A. Eatman. 1998. The cloning and expression of human deoxyribonuclease II. A possible role in apoptosis. J. Biol. Chem. 273: 30909-30914.

Kroemer, G., N. Zamzami, and S.A. Susin 1997. Mitochondrial control of apoptosis. Immunol. Today 18: 43-51.

Kwok, Y. and L.H. Hurley. 1998. Topoisomerase II site-directed alkylation of DNA by peorospermin and its effect on topoisomerase II-mediated DNA cleavage. I. Biol. Chem. 273: 33020-33026.

Lagarkova, M.A., O.V. Iarovaia, and S.V. Razin. 1995. Largescale fragmentation of mammalian DNA in the course of apoptosis proceeds via excision of chromosomal DNA loops and their oligomers. J. Biol. Chem. 270: 20239-42021.

Liu, L.F. 1989. DNA topoisomerase poisons as antitumor drugs. Annu. Rev. Biochem. 58: 351-375.

Liu, L.F., T.C. Rowe, L. Yang, K. Tewey, and G.L. Chen. 1983. Cleavage of DNA by mammalian DNA topoisomerase II. $)$. Biol. Chem. 258: 15365-15370.

Liu, X., H. Zou, C. Slaughter, and X. Wang. 1997. DFF, a heterodimeric protein that fuctions downstream of caspase-3 to trigger DNA fragmentation during apoptosis. Cell 89: 175-
184.

Lowe, S.W., H.E. Ruley, T. Jacks, and D.E. Housman. 1993. p53-dependent apoptosis modulate the cytotoxicity of antitumor drugs. Cell 74: 957-967.

Oberhammer, F., J.W. Wilson, C. Dive, I.D. Morris, J.A. Hickman, A.E. Walker, and M. Sikorska. 1993. Apoptotic death in epithelial cells: Cleavage of DNA to 300 and/or $50 \mathrm{~kb}$ fragments prior to or in the presence of internucleosomal fragmentation. EMBO J. 12: 3679-3684.

Poljak, L. and E. Kas. 1995. Resolving the role of topoisomerase II in chromatin structure and function. Trends Cell Biol. 5: 348-354.

Quillet-Mary, A., J-P. Jaffrezou, V. Mansat, C. Bordier, J. Naval, and G. Laurent. 1995. Implication of mitochondrial hydrogen peroxide generation in ceramide-induced apoptosis. $I$. Biol. Chem. 272: 21388-21395.

Sakahira, H., M. Enari, and S. Nagata. 1998. Cleavage of CAD inhibitor in CAD activation and DNA degradation during apoptosis. Nature 391: 96-99.

Shih, S.C. and O. Shaman. 1996. Cell cycle-dependent tumor necrosis factor apoptosis. Cancer Res. 57: 1591-1601.

Sinclair, D.A. and L. Guarente. 1997. Extrachromosomal rDNA circles-a cause of aging in yeast. Cell 91: 1033-1042.

Stangel, M., U.K. Zettl, E. Mix, J. Zielasek, K.V. Toyka, H.P. Hartung, and R. Gold. 1996. $\mathrm{H}_{2} \mathrm{O}_{2}$ and nitric oxide-mediated oxidative stress induce apoptosis in rat skeletal muscle myoblasts. J. Neuropathol. Exp. Neurol. 55: 36-43.

Stanulla, M., J. Wang, D.S. Chervinsky, S. Thandla, and P.D. Aplan. 1997. DNA cleavage within the MLL breakpoint cluster region is a specific event which occurs as part of higherorder chromatin fragmentation during the initial stages of apoptosis. Mol. Cell. Biol. 17: 4070-4079.

Sun, X.M. and G.M. Cohen. 1994. $\mathrm{Mg}(2+)$-dependent cleavage of DNA into kilobase pair fragments is responsible for the initial degradation of DNA in apoptosis. I. Biol. Chem. 269: $14857-14860$.

Tewey, K.M., T.C. Rowe, L. Yang, B.D. Halligan, and L.F. Liu. 1984. Adriamycin induced DNA damage mediated by mammalian topoisomerase II. Science 226: 466-468.

Um, H.D., J.M. Orenstein, and S.M. Wahl. 1996. Fas mediates apoptosis in human monocytes by a reactive oxygen intermediate dependent pathway. J. Immunol. 156: 3469-3477.

Walker, P.R., C. Smith, T. Youdale, J. Leblanc, J.F. Whitfield, and M. Sikorska. 1991. Topoisomerase II-reactive chemotherapeutic drugs induce apoptosis in thymocytes. Cancer Res. 51: 1078-1085.

Wang, J.C. 1996. DNA topoisomerases. Annu. Rev. Biochem. 65: 635-692.

Wasserman, R.A., C.A. Austin, L.M. Fisher, and J.C. Wang. 1993. Use of yeast in the study of antitumor drugs targeting DNA topoisomerases: Expression of a functional recombinant human topoisomerase IIa in yeast. Cancer Res. 53: 3591-3596.

Zechiedrich, E.L., K. Christiansen, A.H. Anderson, O. Westergaard, and N. Ocheroff. 1989. Double-stranded cleavage/religation reaction of eukayotic topoisomerase II: Evidence for a nicked DNA intermediate. Biochemistry 28: 6229-6236.

Zhang, J., X. Liu, D.C. Scherer, L. van Kaer, X. Wang, and M. Xu. 1998. Resistance to DNA fragmentation and chromatin condensation in mice lacking the DNA fragmentation factor 45. Proc. Natl. Acad. Sci. 95: 12480-12485. 


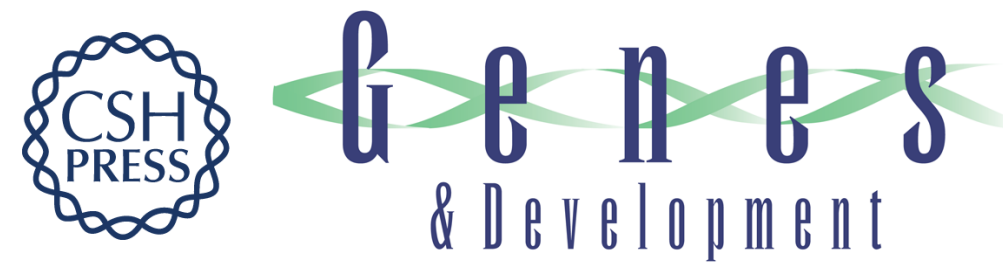

\section{Activation of topoisomerase II-mediated excision of chromosomal DNA loops during oxidative stress}

Tsai-Kun Li, Allen Y. Chen, Chiang Yu, et al.

Genes Dev. 1999, 13:

References This article cites 44 articles, 26 of which can be accessed free at:

http://genesdev.cshlp.org/content/13/12/1553.full.html\#ref-list-1

License

Email Alerting

Receive free email alerts when new articles cite this article - sign up in the box at the top

Service

right corner of the article or click here.

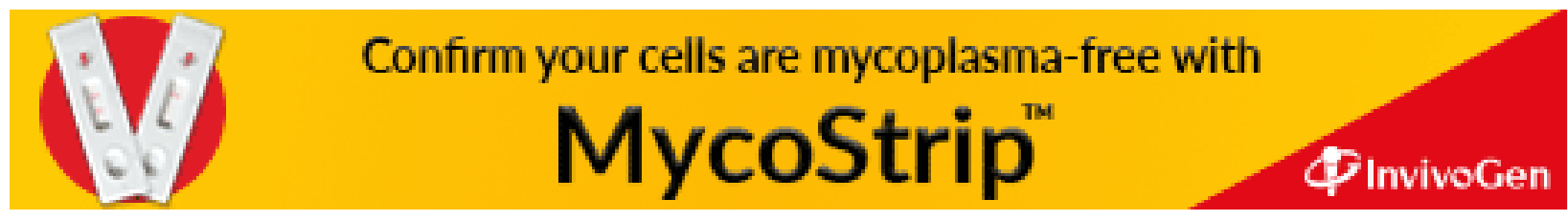

